\title{
Mikrodalga destekli distilasyon ve ekstraksiyon metotlarının rezene (Foeniculum vulgare Mill.) ve anason (Pimpinella anisum L.) meyvelerinin uçucu yăg oranına etkisi
}

\author{
Effects on essential oil content of fennel (Foeniculum vulgare Mill.) and anise \\ (Pimpinella anisum L.) fruits of microwave-assisted distillation and extraction \\ methods
}

\author{
Nimet KARA®, Hasan BAYDAR ${ }^{\circledR}$, Seher ÇAKAN® \\ Isparta Uygulamalı Bilimler Üniversitesi, Tarım Bilimleri ve Teknolojileri Fakültesi, Tarla Bitkileri Bölümü, Isparta \\ Sorumlu yazar (Corresponding author): N. Kara, e-posta (e-mail): nimetkara@isparta.edu.tr \\ Yazar(lar) e-posta (Author e-mail): hasanbaydar@isparta.edu.tr, sehercakan1045@gmail.com
}

\section{MAKALE BİLGİSİ}

Alınıs tarihi 10 Haziran 2019

Düzeltilme tarihi 10 Ocak 2020

Kabul tarihi 13 Ocak 2020

\section{Anahtar Kelimeler:}

Rezene

Anason

Mikrodalga destekli distilasyon

Uçucu yağ

Sabit yağ

\begin{abstract}
$\ddot{\mathbf{O Z}}$
$\mathrm{Bu}$ araştırma, mikrodalga destekli distilasyon uygulamalarının rezene (Foeniculum vulgare Mill.) ve anason (Pimpinella anisum L.) meyvelerinde uçucu yağ ve sabit yağ oranları ile bileșenleri üzerine etkisini araștırmak amacıyla yürütülmüștür. Deneme tesadüf parselleri deneme desenine göre dört tekerrürlü olarak kurulmuştur. Meyvelere 0 (kontrol), 400, 600 ve $800 \mathrm{~W}$ güçte mikrodalga uygulandıktan sonra su distilasyonu yoluyla çıkarılan uçucu yağ oranı rezenede \%0.96'dan (kontrol) \%1.31'e (800 W), anasonda \%1.98'den (kontrol) \%2.10 ( $800 \mathrm{~W}$ )'a artış gösterdiği, anetol oranı ise sırasıyla \%82.67'den (kontrol) \%84.06'ya (400 W) ve $\% 95.75$ 'den (kontrol) \%96.53'e (800 W) artış gösterdiği belirlenmiștir. Mikrodalga uygulanmış meyvelerde damıtma artığı olarak elde edilen posalarda sabit yağ oranı rezenede istatistiksel olarak önemli değișiklik göstermezken (\%27.27-27.87), anasonda \%29.87'den (kontrol) \%30.30'a (800 W) artış göstermiştir. Rezenede sabit yağın en önemli yağ asidi bileşeni olan petroselinik asit oranı ise \%74.86'dan (kontrol) \%78.85'e artış göstermiş, anasonda ise petroselinik asit oranı birbirine yakın olmuştur. Çalışma sonucuna göre, ön işlem olarak milkrodalga uygulamalarının rezene ve anason meyvelerinin uçucu ve sabit yağ verimliliğinde ve kalitesinde olumlu etkisi olduğu tespit edilmiştir.
\end{abstract}

\section{ARTICLE INFO}

Received 10 June 2019

Received in revised form 10 January 2020

Accepted 13 January 2020

\section{Keywords:}

Fennel

Anise

Microwave assisted distillation

Essential oil

Fixed oil

\begin{abstract}
This research was carried out to investigate the effects of microwave assisted distillation applications on essential oil and fixed oil yields and compounds in fennel (Foeniculum vulgare Mill.) and anise (Pimpinella anisum L.) fruits. The experiment was set up as randomized plots design with four replications. When the fruits were hydro-distilled after applying microwave power of 0 (control), 400, 600 and $800 \mathrm{~W}$, the rate of essential oil yield increased from $0.96 \%$ (control) to $1.31 \%(800 \mathrm{~W})$ in fennel, from $\% 1.98$ (kontrol) to $\% 2.10(800 \mathrm{~W})$ in anise and the anethol ratio increased from $82.67 \%$ (control) to $84.06 \%(400 \mathrm{~W}$ ) and from $\% 95.75$ (kontrol) to $\% 96.53$ 'e $(800 \mathrm{~W})$, respectively. While the fixed oil ratio in the distillation residue did not show any significant change (from $27.27 \%$ to $27.87 \%$ ) in fennel, anise increased from $\% 29.87$ (control) to $\% 30.30(800 \mathrm{~W})$. The ratio of petroselinic acid, which is the most important fatty acid component of fixed oil in fennel, was varied from $74.86 \%$ (control) to $78.85 \%$ (800 W), and petroselinik asit ratio in anise was close to each other. According to the results of study, it was determined to be positive effect of the microwave applications as pre-treatment on the essential and fixed oil productivity and quality of fennel and anise fruits.
\end{abstract}




\section{Giriş}

Umbelliferae familyasından Rezene (Foeniculum vulgare Mill.) ve anason (Pimpinella anisum L.), ülkemizde uzun yıllardır kültürü yapılan ve ekonomik değeri olan baharat, ilaç ve uçucu yağ bitkileridir. Ülkemizde anason ve rezene yetiştiriciliğinde özellikle Burdur ili başta olmak üzere Göller Bölgesi tarımsal ve endüstriyel açıdan önemli bir üretim potansiyeline sahiptir. Dünyada rezene en fazla Avrupa ülkelerinde, Hindistan, Mısır, Türkiye, Çin, Arjantin, Endonezya ve Pakistan'da yetiştirilmektedir. Dünyada rezenenin ac1 rezene (Foeniculum vulgare var. vulgare) ve tatl rezene (Foeniculum vulgare var. dulce) olmak üzere başlıca iki farklı kültür varyetesi vardır. Türkiye florasında rezenenin yayılış gösteren ve kültürü yapılan türü ise Foeniculum vulgare Mill. (Baydar 2016) olup, 23400 ha alanda, 3067 ton üretim yapılmakta ve ortalama $131.0 \mathrm{~kg} \mathrm{da}^{-1}$ verim alınmaktadır. Türkiye başta ABD, Almanya, Brezilya, Hollanda, İtalya, İspanya olmak üzere çok sayıda ülkeye yılda 2.52 milyon Dolar değerinde rezene meyvesi ihraç etmektedir (TÜIK 2018). Dünyada anason üretiminde özellikle Hindistan, Suriye, Meksika ve Çin başta gelmektedir. Dünyada anasonun en tanınmış tipleri İtalyan, İspanyol, Alman ve Rus anasonları, ülkemizde Çeşme ve Burdur anasonlarıdır (Ceylan 1987). Türkiye'de anasondan 12445 ha alanda, 8664 ton üretim yapılmakta ve ortalama $70.0 \mathrm{~kg} \mathrm{da}^{-1}$ verim alınmaktadır. Anason ihracatı başta ABD olmak üzere, Almanya, Brezilya, Hollanda, İtalya, Japonya, Hindistan, Yunanistan, İspanya ve Fransa gibi ülkelere yaklaşık 11.55 milyon dolar değerinde gerçekleşmiştir (TÜIK 2018).

Anason ve rezenenin meyvelerinden su/buhar distilasyonu yöntemiyle uçucu yağ solvent ekstraksiyonu yöntemiyle sabit yağ elde edilmektedir (Baydar 2016). Anason \%1.5-3.5, rezene \%2-4 oranında uçucu yağ içermekte ve uçucu yağları ana bileşen olarak trans-anethol (\%75-95) bakımından zengindir (Kara 2015; Baydar 2016). Uçucu yağları dışında meyvelerden solvent ekstraksiyonu ile elde edilen sabit yağları (\%20-30) da çok önemlidir. Umbelliferae familyası bitkilerinin sabit yağları, diğer yă̆ bitkilerinin yağlarında rastlanmayan yağ asitlerinden petroselinik asit (C18:1, cis 6) bakımından çok zengindir (\%55-90); hem yemeklik hem de sanayi yağı olarak kullanılabilmektedir (Baydar 2013; Baydar ve Erbaş 2014).

Anason ve rezene gibi uçucu yağ taşıyan bitkilerde uçucu yağ oranı ve kompozisyonunda genetik ve ekolojik faktörlerin yanı sıra distilasyon yöntemi, distilasyon süresi (Cannon ve ark. 2013) ve distilasyon suyuna eklenen katk1 maddeleri (Shamspur ve ark. 2012)'de etkilidir. Mikrodalgalar, uygulandıkları bitkinin hücrelerindeki su moleküllerini hızla buharlaştırmakta ve buharlaşmaya birlikte ortaya çıkan yüksek basınç hücre membranlarını parçalayarak etkin maddelerin serbest kalmasını sağlayabilir. Mikrodalga uygulamalarında isı nedeniyle meyvelerin nem içerikleri azalmakta ve kuru madde miktarı artarak etkili madde miktarı yükselebilir (Karabacak ve ark. 2015). Serbest kalan etkin maddeler ekstraksiyon veya distilasyon teknikleri ile izole edilerek kazanılmaktadır.

Mikrodalga ekstraksiyonu diğer klasik ekstraksiyon ve distilasyon teknikleri ile kolayca kombine edilerek kısa sürede yüksek verim ve kalitede ekstrakt elde edilmesini mümkün kılmaktadır (Baydar 2016). Mikrodalga firınında ekstraksiyon veya distilasyon sürecinde uygulanan güç $(\mathrm{W})$ ve süre (dakika) ekstrakt verimi ve kalitesi üzerine doğrudan etki etmektedir. Mikrodalga destekli distilasyon ve ekstraksiyon teknikleri sayesinde daha kısa sürede, daha düşük maliyette, daha yüksek verimlilikte, saflıkta ve kalitede bitki ekstraktları elde edilebilmektedir.

$\mathrm{Bu}$ araştırmada, mikrodalga firınında 3 farklı güçte (400, 600 ve $800 \mathrm{~W})$ mikrodalga uygulamasının, rezene ve anason meyvelerinin uçucu ve sabit yağ oranı ve kalitesi üzerine etkisi belirlenmiştir.

\section{Materyal ve Yöntem}

Araştırma, Isparta Uygulamalı Bilimler Üniversitesi Ziraat Fakültesi Tarla Bitkileri Bölümü laboratuvarında Burdur'dan temin edilen rezene (Foeniculum vulgare Mill.) ve anason (Pimpinella anisum L.) populasyonları kullanılarak tesadüf parselleri deneme desenine göre dört tekerrürlü olarak yürütülmüştür. Uçucu yağ oran1, Clevenger cihazında hidrodistilasyon yöntemi ile belirlenmiştir. Distilasyon işleminde her bir uygulama için rezene ve anason meyveleri 20 gram tartılmış ve üzerine $200 \mathrm{ml}$ saf su (1:10) eklendikten sonra damitma balonuyla birlikte mikrodalga firınına yerleştirilmiştir (kontrol için mikrodalga uygulaması yapılmamıştır). Mikrodalga firınında $(250 \mathrm{~V}, 50 \mathrm{~Hz}, 2450 \mathrm{MHz}) 3$ farklı güçte $(400 \mathrm{~W}$, $600 \mathrm{~W}$ ve $800 \mathrm{~W}) 4$ tekrarlı olarak mikrodalga uygulamas yapılmıştır. Mikrodalga firında her bir güç uygulamasında kaynama başladığı anda (400 W: 3.35 dak., $600 \mathrm{~W}: 2.25$ dak. ve $800 \mathrm{~W}: 1.45$ dak.) kaynatma işlemi sonlandırılmıştır. Daha sonra Clevenger aparatında 2 saat süreyle damıtılarak uçucu yăg oranları (\%, v/w) belirlenmiştir (European Pharmacopoeia 1975).

Her bir uçucu yağ örneğinin uçucu yağ bileşenleri GC/MS (Gas chromatography/Mass spectrometry) cihazında (QP-5050 quadrapole detektörlü Shimadzu 2010 Plus) CP-Wax 52 CB $(50 \mathrm{~m} \times 0.32 \mathrm{~mm}, \quad 0.25 \mu \mathrm{m})$ kapiler kolonu kullanılarak belirlenmiştir. Analizlerde firın sıcaklık programı dakikada $10^{\circ} \mathrm{C}$ artarak $60^{\circ} \mathrm{C}$ 'den $220^{\circ} \mathrm{C}$ 'ye ulaşmış ve $220^{\circ} \mathrm{C}$ 'de 10 dakika kadar bekletilmiştir. Toplam koşturma süresi 60 dakika, enjektör sicaklığ $240^{\circ} \mathrm{C}$ ve detektör sicaklığı $250^{\circ} \mathrm{C}$ olarak ayarlanmıştır. Taşıyıcı gaz olarak helyum gazı (20 ml dakika-1, split 1:20) kullanılmıştır.

Clevenger düzeneği ile distile edilen her bir numuneye ait posa kurutulup ögütüldükten sonra nükleer manyetik rezonans (NMR) cihazında sabit yağ oranları (\%) tespit edilmiştir. Sabit yağda yağ asitlerinin belirlenmesi amacıyla uçucu yağ alınmış $3 \mathrm{~g}$ kurutulmuş ve ögütülmüş posa üzerine $5 \mathrm{ml}$ n-hekzan eklenerek cam baget yardımıyla iyice karıştırılmıştır. Ağzı kapalı olarak bir gece bekletildikten sonra (soğuk ekstraksiyon) üst fazda toplanan berrak yağlı solvent pipetle alınarak başka bir temiz tüpe aktarılmıştır. Bu tüpler ağzı açık olarak kurutma firınında tutularak solvent iyice uçurulup geride kalan saf sabit yağ türevlendirmeye (esterleştirmeye) alınmıştır. Posanın soğuk ekstraksiyon yağı $(100 \mu \mathrm{l}) \% 0.5$ sodyum metoksit (80:20, methanol: iso-oktan) içeren türevlendirici içinde 24 saat oda sıcaklığında bekletilip üzerine $1 \mathrm{ml}$ iso-oktan eklendikten sonra vortekslenip üst fazın ayrılması beklenmiş ve esterleşmiş yağ asitlerinin (FAME) toplandığ üst fazdan $1 \mu$ l çekilerek gaz kromatografisi (GC-FID) cihazına enjekte edilmiştir. (Cihaz: Perkin Elmer Auto System XL, kolon: CP sil 88 for FAME, $50 \mathrm{~m} \times 0.25 \mathrm{~mm}, 0.25 \mu \mathrm{m})$, firın sicaklığ 1 programı: $80^{\circ} \mathrm{C}$ 'de 4 dak. (rate: 0) // $175^{\circ} \mathrm{C}$ de 25 dak. (rate $10^{\circ} \mathrm{C}$ dakika ${ }^{-1}$.) // $215^{\circ} \mathrm{C}^{\prime}$ de 2 dak. (rate $4{ }^{\circ} \mathrm{C}$ dakika ${ }^{-1}$ ) ve $240^{\circ} \mathrm{C}^{\prime}$ de 10 dak. (rate $2^{\circ} \mathrm{C}$ dakika-1). Enjektör ve detektör sıcaklığ $1240^{\circ} \mathrm{C}$, taşıyıcı gaz: He (15 PSI), split oranı: $1 / 20 \mathrm{ml} \mathrm{dakika}^{-1}$, enjeksiyon miktarı: 1 $\mu \mathrm{l}$. 
Elde edilen sayısal veriler 4 tekerrürlü olarak SAS istatistik programı yardımıyla değerlendirilmiş ve $F$ testi yapılarak ortalamalar arasındaki farklılıklar LSD Testine göre karşılaştırılarak yorumlanmıştır.

\section{Bulgular ve Tartışma}

\subsection{Uçucu Yă̆ Oranları}

Mikrodalga destekli su distilasyonu uygulamaları sonucu rezene meyvelerinden elde edilen toplam uçucu yağ ve bileşen oranları Çizelge 1'de sunulmuştur. Ön işlem olarak yapılan mikrodalga uygulamaları rezene meyvelerinin uçucu yă oranında istatistiksel olarak önemli $(\mathrm{P}<0.01)$ artışlara neden olmuştur. Mikrodalga uygulanmayan (kontrol) rezene meyvelerde su distilasyonu ile $\% 0.96$ oranında uçucu yağ oranı elde edilirken, ön işlem olarak $400 \mathrm{~W}, 600 \mathrm{~W}$ ve $800 \mathrm{~W}$ güçte mikrodalga uygulamaları yapıldığında uçucu yağ oranları sırasıyla $\% 0.96, \% 1.16$ ve $\% 1.31$ olarak tespit edilmiştir (Çizelge 1). GC-MS analiz sonuçlarına göre rezene uçucu yağında oranları $\% 0.5$ 'in üzerinde olan 22 farklı uçucu yağ bileşeni tespit edilmiştir. Bu bileşenler arasında oransal olarak en fazla temsil edilen bileşenlerin sırasıly anetol (\%81.5284.06), p-allianisol (\%5.25-6.12), anisaldehit (\%3.95-4.28), limonen (\%2.97-4.50) ve fenkon (\%1.65-1.98) olduğu belirlenmiştir. Rezene uçucu yağının en önemli bileşeni olan anetol miktarı $400 \mathrm{~W}$ uygulamasında $\% 84.06$ ile en yüksek oranda tespit edilmiş, bundan daha yüksek güçteki mikrodalga uygulamalarda azalış göstererek kontrole yakın değerler göstermiştir (Çizelge 1).

Farklı mikrodalga güçleri uygulamalarının anason meyvelerinin uçucu yağ oranları üzerine etkisi Çizelge 2'de gösterilmiştir. Anason meyvelerine farklı güçte uygulanan mikrodalgalar arasında istatistiksel olarak fark çıkmamış, ancak uçucu yağ oranı güç artışına bağlı olarak kontrolden $800 \mathrm{~W}$ (\%1.98 ile \%2.10)'a doğru artış göstermiştir (Çizelge 2).

Anason meyvelerinde toplam 4 tane uçucu yağ bileşeni belirlenmiş ve uçucu yağ ana bileşenleri olarak anetol ve estragol (metil kavikol) tespit edilmiştir. Anetol bakımından uygulamalar arasında fark çıkmamış, en yüksek anetol oranı $600 \mathrm{~W}(\% 96.73)$ güçten elde edilirken, estragol oranı kontrole göre tüm uygulamalarda daha düşük oranlarda tespit edilmiştir. En düşük estragol oranının \%2.64 ile yine $600 \mathrm{~W}^{\prime} l \mathrm{lk}$ mikrodalga gücünde tespit edilmiştir (Çizelge 2).

Şekil 1 ve Şekil 2'de mikrodalga destekli distilasyon uygulamalarının rezene ve anason meyvelerinde 30, 60, 90 ve 120 dakikalık distilasyon aşamalarında uçucu yağ kazanımı üzerine etkisi gösterilmiştir. Toplam 2 saat (120 dakika) süren

Çizelge 1. Mikrodalga destekli su distilasyon uygulamalarında rezene meyvelerinin uçucu yağ oranı ve bileşenleri.

Table 1. Essential oil content and composition of fennel fruits in microwave-assisted water distillation treatments.

\begin{tabular}{|c|c|c|c|c|c|}
\hline Bileşenler & $\mathrm{Rt}$ & $0 \mathrm{~W}$ (Kontrol) & $400 \mathrm{~W}$ & $600 \mathrm{~W}$ & $800 \mathrm{~W}$ \\
\hline$\alpha$-pinen & 6.74 & 0.14 & 0.14 & 0.17 & 0.15 \\
\hline$\beta$-Fellandren & 8.16 & - & 0.06 & - & 0.09 \\
\hline Sabinen & 8.17 & 0.08 & - & 0.09 & - \\
\hline Simol & 10.39 & - & 0.13 & - & 0.19 \\
\hline p-simen & 10.42 & 0.16 & - & 0.17 & - \\
\hline Limonen & 10.65 & 3.73 & 2.97 & 4.50 & 4.19 \\
\hline 1,8-sineol & 10.79 & 0.20 & 0.16 & 0.21 & 0.20 \\
\hline Cis-osimen & 10.95 & 0.12 & 0.09 & 0.13 & 0.14 \\
\hline Fenkon & 13.71 & 1.98 & 1.65 & 1.93 & 1.98 \\
\hline Cis-limonen oksit & 16.23 & 0.07 & - & 0.07 & 0.07 \\
\hline Kamfor & 17.02 & 0.06 & - & - & 0.05 \\
\hline p-allianisol & 20.00 & 5.89 & 5.25 & 6.07 & 6.12 \\
\hline t-karveol & 21.65 & 0.05 & - & 0.06 & - \\
\hline Benzalaldehit & 22.98 & - & 0.06 & - & 0.06 \\
\hline 2-siklohekzen & 23.18 & 0.34 & 0.29 & 0.24 & 0.28 \\
\hline Anisaldehit & 23.99 & 3.95 & 3.95 & 4.28 & 3.98 \\
\hline Anetol & 26.69 & 82.67 & 84.06 & 81.52 & 81.99 \\
\hline p-Asetonilanisol & 32.12 & - & 0.12 & - & 0.25 \\
\hline Propanon & 32.24 & 0.37 & - & 0.14 & - \\
\hline Karyofillen & 34.46 & - & 0.11 & - & - \\
\hline$\alpha$-humulen & 36.72 & - & 0.38 & 0.09 & - \\
\hline Laden & 45.20 & - & 0.45 & 0.07 & - \\
\hline Uçucu yağ oranı (\%) & & $0.96 \mathrm{c}^{*}$ & $0.96 \mathrm{c}$ & $1.16 \mathrm{~b}$ & $1.31 \mathrm{a}$ \\
\hline
\end{tabular}

Çizelge 2. Mikrodalga destekli su distilasyon uygulamalarında anason meyvelerinin uçucu yağ oranı ve bileşenleri.

Table 2. Essential oil content and composition of anise fruits in microwave-assisted water distillation treatments.

\begin{tabular}{lrrrr}
\hline Bileşenler & Rt & $0 \mathrm{~W}$ (kontrol) & $400 \mathrm{~W}$ & $600 \mathrm{~W}$ \\
\hline Estragol & 20.1 & 3.20 & 2.98 & $800 \mathrm{~W}$ \\
Trans-anetol & 26.2 & 95.75 & 96.19 & 2.64 \\
B-chamigrene & 38.0 & 0.23 & 9.28 & 96.73 \\
Isoeugenol & 58.5 & 0.82 & 0.55 & 0.26 \\
\hline Uçucu Yağ Oranları (\%) & & 1.98 & 1.98 & 0.37 \\
\hline
\end{tabular}

Uçucu yağ oranı için aynı harflerle gösterilen ortalamalar arasındaki farklılıklar istatistiksel olarak önemli değildir $\left(\mathrm{F}\right.$ değeri= $2.36^{\text {ö.d }}$, V.K.=\%2.76). 


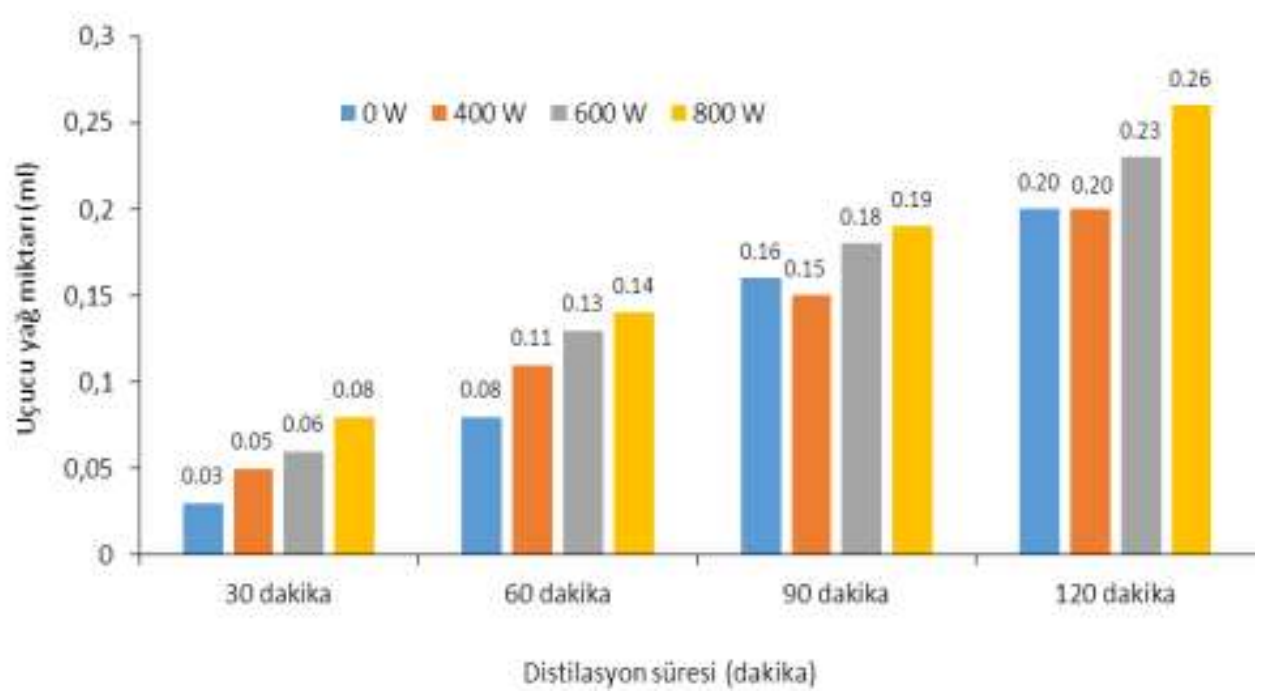

Şekil 1. Mikrodalga destekli distilasyon uygulamalarının rezene meyvelerinde distilasyon sürecinde uçucu yağ kazanımı üzerine etkisi. Figure 1. Effect on essential oil recovery during the distillation process in fennel fruits of microwave-assisted distillation treatment.

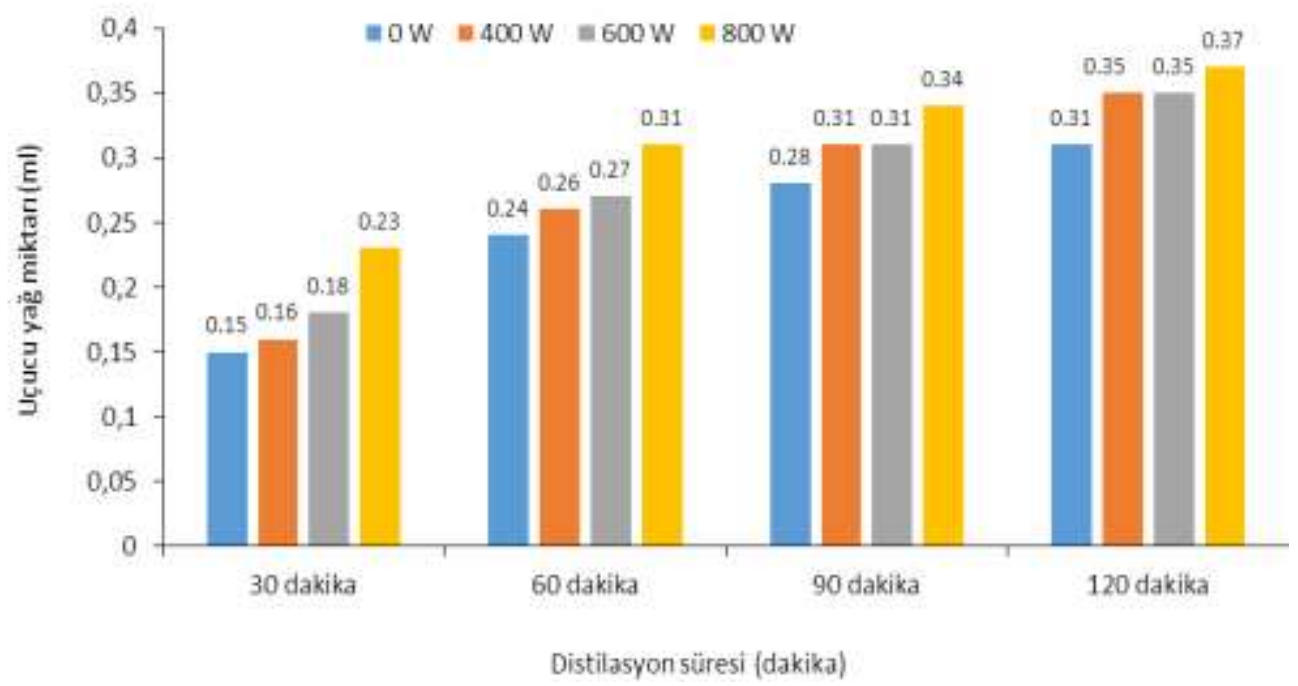

Şekil 2. Mikrodalga destekli distilasyon uygulamalarıın anason meyvelerinde distilasyon sürecinde uçucu yağ kazanımı üzerine etkisi.

Figure 2. Effect on essential oil recovery during the distillation process in anise fruits of microwave-assisted distillation treatment.

distilasyon süresinin ilk 30 dakikası içinde $0,400,600$ ve 800 $\mathrm{W}$ mikrodalga uygulamalarında sirasiyla rezenede $0.03,0.05$, 0.06 ve $0.08 \mathrm{ml}$, anasonda $0.15,0.16,0.18$ ve $0.23 \mathrm{~mL}$ uçucu yağ kazanılmış, bu sıralama diğer distilasyon dilimlerinde de benzer şekilde artarak devam etmiş̧ir (Şekil 1). Sonuç olarak belirli bir güç ve belirli bir süre için mikrodalgalara maruz kalan hücre duvarları veya zarları ortaya çıkan yüksek sıcaklık ve basınç etkisiyle parçalanarak uçucu yağların daha kısa sürede ve daha yüksek miktarlarda açığa çıkmasına neden olmaktadır.

Fazlali ve ark. (2015) biberiye yapraklarının su distilasyonu ile 90 dakika damıtılması ile uçucu yağ oranı \%1.3, $900 \mathrm{~W}$ güçte mikrodalga destekli su distilasyonu yöntemi ile 30 dakika damıtmasından \%1.5 oranında uçucu yağ elde etmişlerdir. Akgül (1986) tatlı rezene meyvelerinde uçucu yağ oranının \%1.7-2.5, Özkan ve Gürbüz (2000) \%1.93-2.28 ve Keskin ve Baydar (2016) \%2.20-3.13 arasında değiştiğini uçucu yağının ana bileşeni olan anetol oranının \%79.67-89.13 arasında değiştiğini bildirmişlerdir. Akgül (1986) tatlı rezene meyve örneklerinde uçucu yağ oranının \%1.7-2.5 arasında değiştiğini ve uçucu yağlarında trans-anetol (\%75.6-86.5), limonen (\%4.2-9.1), estragol (\%3.2-5.2), fenkon (\%1-2.8), $\gamma$-terpinen (\%0.8-1.5) ve $\alpha$-pinen (\%0.4-1.1) arasında bulunduğunu belirlemiştir. Kan ve ark. (2006) rezene meyvelerinin uçucu yağ bileşenlerinin yetiştirme koşullarına göre değiştiğini ana bileşenleri trans-anetol (\%60.6-87.0), anisaldehit, estragol, $\alpha$-fenkon, limonen, karvon ve cis-anetol olduğunu tespit etmiştir. Kiralan (2012) mikrodalga firınında 2, 4 ve 8 dakika boyunca $0.45 \mathrm{~kW}$ 'de kavrulmuş çörek otunun uçucu yağ bileşen oranlarının kavrulma ile azaldığını bildirmiştir

Doğan ve ark. (2018) anasonun uçucu yă̆ oranının \%1.21-3.88 arasında değiştiğini, Satıbeşe ve ark. (1994) anasonun uçucu yağının çok büyük bir miktarının trans-anetol (ortalama \%98.0) olduğunu, Kara (2015) anasonun temel uçucu yağ bileşenlerinin trans-anetol (\%97.57), anisol-p-allyl (\%1.80) ve karyofillen (\%1.30) olduğunu bildirmişlerdir. 


\subsection{Sabit Yağ Oranı ve Yă̆ Asitleri}

Ön işlem olarak farklı güçlerde ve sürelerde mikrodalga uygulanmış rezene meyvelerinin su distilasyonu sonrasında atık ürün olarak elde edilen uçucu yağı alınmış rezene posasının kurutulup öğütüldükten sonra elde edilen sabit yağ oranı ve yağ asitleri bileşenleri Çizelge 3'te sunulmuştur. Kontrol, 400, 600 ve $800 \mathrm{~W}$ mikrodalga uygulanmış rezene meyvelerinin damıtma posalarının NMR sabit yağ oranları sırasıly \%27.27, 27.87, 27.16 ve 27.85 olarak tespit edilmiş, ortalamalar arası farklılıklar istatistiksel olarak önemli bulunmamıştır. Her bir uygulamadan elde edilen sabit yağların yă asitleri kompozisyonu Çizelge 3 'te verilmiştir. GC-FID analizine göre rezene sabit yağını meydana getiren en önemli doymuş yağ asitlerinin palmitik ve stearik asit, en önemli doymamış yağ asitlerinin ise geliş sırasına göre miristoleik, petroselinik, oleik, cis-vassinik ve linoleik olduğu belirlenmiştir (Çizelge 3). Stearik, oleik ve cis-vassinik asit dışındaki yağ asitleri ön işlem olarak mikrodalga 1şınlarından istatistiksel olarak önemli düzeylerde etkilenmişlerdir. Genel olarak mikrodalga gücü artışına bağlı olarak miristoleik asit \%9.57'den \%5.09'a ve palmitik asit \%3.77'den \%3.60'a azalış, linoleik asit ise \%0.96'dan \%1.22'ye artış göstermiştir (Çizelge 3).

Diğer Umbelliferae türlerinde olduğu gibi rezene sabit yağının da en önemli yağ asidinin petroselinik asit olduğu tespit edilmiştir. Petroselinik asit oranı mikrodalga uygulamalarından önemli düzeyde $(\mathrm{P}<0.01)$ etkilenmiş, mikrodalga firınının güç artışına bağlı olarak sırasıyla \%74.86, \%77.33, \%78.77 ve \%78.85 oranlarında artan değerler elde edilmiştir (Çizelge 3).
$\mathrm{Bu}$ sonuçlar, ön işlem olarak mikrodalga uygulamasının rezene damıtma posasında sabit yağ oranını etkilemezken, sabit yağın en önemli bileşeni olan petroselinik asidi önemli olarak arttırdığı saptanmıştır.

Ön işlem olarak farklı güçlerde ve sürelerde mikrodalga uygulanmış anason meyvelerinin sabit yağ oranları arasında ise istatistiksel olarak $(\mathrm{P}<0.05)$ fark ortaya çıkmış, mikrodalga 1sı artışına bağlı olarak sabit yağ oranı yükselmiştir. Her bir uygulamadan elde edilen anason meyvelerinin sabit yağ oranları ve yağ asitleri kompozisyonu Çizelge 4'te verilmiştir. En düşük sabit yă oranı kontrolden $(\% 29.87)$ ve en yüksek sabit yă oran 1 ise 600 ve $800 \mathrm{~W}(\% 30.29$ ve \%30.30) mikrodalga uygulamasından elde edilmiştir.

Anason meyvelerinin sabit yağında yağ asitleri kompozisyonu büyük oranda petroselinik asit (\%60.98) ve linoleik asitten (\%20.65) oluşmuştur. Mikrodalga uygulamaları arasında yağ asitleri oranları bakımından önemli farklılık oluşmamıştır (Çizelge 4).

Bayrak (2006) rezene meyvesinde \%12.71-16.61 arasinda sabit yağ bulunduğunu, en fazla petroselinik asit \%45.09-58.40, laurik asit \%24.61-39.33 yer alırken bunu sirası ile linoleik asit \%6.55-9.74, palmitik asit \%3.20-3.80, oleik asit \%2.55-3.25 ve diğer eser miktardaki bileşenlerin takip ettiğini tespit etmiştir. Keskin ve Baydar (2016) rezene sabit yağ oran1 \%22.27-23.70 arasında değiştiğini ve sabit yağda en fazla bulunan petroselinik asit oranının \%83.29-83.49 arasında değiştiğini bildirmişlerdir.

Çizelge 3. Mikrodalga destekli su distilasyon uygulamalarında rezene meyvelerinin sabit yağ oranı ve bileşenleri.

Table 3. Fixed oil content and its components of fennel fruits of microwave-assisted water distillation treatments.

\begin{tabular}{|c|c|c|c|c|}
\hline Bileşenler & $0 \mathrm{~W}$ (Kontrol) & $400 \mathrm{~W}$ & $600 \mathrm{~W}$ & $800 \mathrm{~W}$ \\
\hline Miristoleik & 9.57 & 7.46 & 6.13 & 5.09 \\
\hline Palmitik & 3.77 & 3.59 & 3.61 & 3.60 \\
\hline Stearik & 1.28 & 1.34 & 1.30 & 1.40 \\
\hline Petroselinik & 74.86 & 77.33 & 78.77 & 78.85 \\
\hline Oleik & 0.18 & 0.10 & 0.57 & 0.17 \\
\hline Cis-vassinik & 9.41 & 9.47 & 9.45 & 9.24 \\
\hline Linoleik & 0.96 & 0.67 & 0.61 & 1.22 \\
\hline Sabit yağ oranları (\%) & 27.27 & 27.87 & 27.16 & 27.85 \\
\hline F değeri Yağ oranı $_{1}$ & \multicolumn{4}{|c|}{$2.45^{\text {̈̈d }}$} \\
\hline $\mathrm{VK}_{\text {Yağ oranı }}$ & \multicolumn{4}{|c|}{1.75} \\
\hline
\end{tabular}

Çizelge 4. Mikrodalga destekli su distilasyon uygulamalarında anason meyvelerinin sabit yağ oranı ve bileşenleri.

Table 4. Fixed oil content and its components of anise fruits of microwave-assisted water distillation treatments.

\begin{tabular}{|c|c|c|c|c|}
\hline Bileşenler & $0 \mathrm{~W}$ (Kontrol) & $400 \mathrm{~W}$ & $600 \mathrm{~W}$ & $800 \mathrm{~W}$ \\
\hline Miristik asid & 0.15 & 0.23 & 0.21 & 0.23 \\
\hline Cis- 10- Pentadekonoik asid & 3.28 & 3.25 & 322 & 3.29 \\
\hline Palmitik asid & 3.50 & 3.79 & 4.63 & 3.07 \\
\hline Stearik asid & 0.81 & 1.21 & 0.78 & 0.92 \\
\hline Petroselinik & 60.98 & 61.05 & 60.93 & 61.67 \\
\hline Oleik asid & 10.1 & 9.40 & 9.41 & 8.37 \\
\hline Cis-vassinik & 0.30 & 0.31 & 0.28 & 0.31 \\
\hline Linoleik asid & 20.65 & 20.35 & 20.25 & 20.63 \\
\hline Arasidik asid & 0.18 & 0.25 & 0.25 & 0.26 \\
\hline Sabit yağ oanları (\%) & $29.87 \mathrm{~B}$ & $30.21 \mathrm{AB}$ & $30.29 \mathrm{~A}$ & $30.30 \mathrm{~A}$ \\
\hline F değeriYağ oranı & \multicolumn{4}{|c|}{$8.60^{*}$} \\
\hline LSD $(\%)_{\text {Yağ oranı }}$ & \multicolumn{4}{|c|}{0.366} \\
\hline VK Yağ oranı & \multicolumn{4}{|c|}{4.1} \\
\hline
\end{tabular}




\section{Sonuç}

Rezene ve anason meyvelerinde 0 (Kontrol) ve ön işlem 400,600 ve $800 \mathrm{~W}$ güçte mikrodalga uygulandiktan sonra su distilasyonu yoluyla elde edilen uçucu yağ oranı rezene ve anasonda sirasiyla \%0.96'dan (kontrol) \%1.31'e (800 W) ve $\% 1.98$ 'den (kontrol) \%2.10'a $(800 \mathrm{~W})$, anetol oran1 ise $\% 82.67$ 'den (kontrol) \%84.06'ya (400 W) ve \%95.75'den (kontrol) \%96.73'e (600 W) artı̧ gösterdiği belirlenmiştir. Ön işlem olarak mikrodalga uygulanmış rezene meyvelerinden damıtma artığı olarak elde edilen posalarda sabit yağ oranı önemli değişiklik göstermezken, anasonda önemli bulunmuştur (sırasıyla \%27.27-27.87 ve \%29.87-30.30 arasında değişmiştir). Rezenede petroselinik asit oran $\% 74.86$ 'dan (kontrol) \%78.85'e artış gösterirken, anasonda önemli bir atış olmamıștır. Sonuç olarak mikrodalga destekli ön uygulamaların etkisi bitki çeşitlerine göre uçucu ve sabit yağ oranlarında değişkenlik göstermiştir.

\section{Teşekkür}

$\mathrm{Bu}$ çalışmada Rezene bitkisine ait laboratuvar araştırma kısmı Türkiye Bilimsel ve Teknolojik Araştırma Kurumu (TÜBİTAK) tarafindan 2209/A Üniversite Öğrencileri Yurt İçi/Yurt Dışı Araştırma Projeleri Destekleme Programı kapsamında desteklenmiştir.

\section{Kaynaklar}

Akgül A (1986) Türkiye'de yetişen rezenelerin (Foeniculum vulgare Mill.) uçucu yağlarının bileşimi üzerine bir araştırma. Doğa Türk Tarım ve Ormancılık Dergisi 10: 301-307.

Baydar H (2013) Tibbi ve Aromatik Bitkiler Bilimi ve Teknolojisi (Genişletilmiş 4. Baskı). Süleyman Demirel Üniversitesi Yayın No: 51 (ISBN: 975-7929- 79-4).

Baydar H, Erbaş S (2014) Yağ Bitkileri Bilimi ve Teknolojisi. SDÜ Yayınları, Yayın No: 97, Isparta.

Baydar H (2016) Tibbi ve Aromatik Bitkiler Bilimi ve Teknolojisi (Genişletilmiş 5. Baskı). Süleyman Demirel Üniversitesi Yayın No: 51 (ISBN: 975-7929-79-4)

Bayrak A (2006) Çeşitli baharat meyvesi (Rezene, Çemenotu) yağlarının sterol ve yağ asidi bilesimi. Ankara Üniversitesi Bilimsel Araştırma Projesi Kesin Raporu Ankara.

Cannon JB, Cantrella CL, Astatkieb T, Zheljazkovc VD (2013) Modification of yield and composition of essential oils by distillation time. Industrial Crops and Products 41: 214-220.

Ceylan A (1987) T1bbi Bitkiler II. Ege Üniversitesi Ziraat Fakültesi Yayınları, İzmir, s. 481.

Doğan Ö, Kara N, Tonguç M (2018) Anason populasyonlarında verim, uçucu yağ oranı ve genetik ilişkilerin araştırılması. Black Sea Journal of Agriculture 1(4): 110-116.

European Pharmacopoeia (1975) European Pharmacopoeia Commission, Maisonneuve 1975, Series: European treaty series, no. 50. Edition.

Fazlali A, Moradi S, Hamedi H (2015) Studying of optimization condition of rosemary essence extraction with microwave assisted hydro-distillation method. American Journal of Essential Oils and Natural Products 3(1): 46-50.

Kan Y, Kartal M, Aslan S, Yıldırım N (2006) Farklı koşullarda yetiştirilen rezene meyvelerinin uçucu yağ bileşenleri. Ankara Üniversitesi Eczacilık Fakültesi Dergisi 35(2): 95-101.

Kara N (2015) Yield, quality and growing degree-days of anise (Pimpinella anisum L.) under different agronomic practices. Turkish Journal of Agricultural and Forestry 39: 1014-1022.
Karabacak AÖ, Sinir GÖ, Suna S (2015) Mikrodalga ve mikrodalga destekli kurutmanın çeşitli meyve ve sebzelerin kalite parametreleri üzerine etkisi. Uludağ Üniversitesi Ziraat Fakültesi Dergisi 29(2): 125-135.

Keskin S, Baydar H (2016) Umbelliferae familyasından bazı önemli kültür türlerinin Isparta ekolojik koșullarında tarımsal ve teknolojik özelliklerinin belirlenmesi. Süleyman Demirel Üniversitesi Fen Bilimleri Enstitüsü Dergisi 20(1): 133-141.

Kiralan M (2012) Volalite compouns of black cumin seeds (Nigella sativa L.) from microwave-heating and conventional roasting. Journal of Food Science 77(4): 481-484.

Özkan F, Gürbüz B (2000) Tatlı rezene (Foeniculum vulgare Mili. var. dulce )'de bitki sıklığının verim ve verim özellikleri üzerine etkileri. Tarla Bitkileri Merkez Araştırma Enstitüsü Dergisi 9: 1-2.

Satıbeşe E, Doğan A, Yavaş İ (1994) Anason tohumu uçucu yağının bileşimi üzerine depolama süresinin etkisi. Gıda 19: 295-299.

Shamspur T, Mohamadi M, Mostafavi A (2012) The effects of onion and salt treatments on essential oil content and composition of Rosa damascena Mill. Industrial Crops and Products 37: 451-456.

TÜIK (2018) Türkiye İstatistik Kurumu Tarımsal İstatistik Verileri, Ankara. www.tuik.gov.tr. Erişim 25 Şubat 2019. 